\title{
Manual hyperinflation and the role of physical therapy in intensive care and emergency units
}

\author{
Hiperinsuflação manual e atuação fisioterapêutica em \\ unidades de terapia intensiva e emergenciais
}

\author{
Rafael Vinícius Santos Cruz ${ }^{[a]}$, Fabiana do Socorro da Silva Dias de Andrade ${ }^{[b]}$, \\ Pollyanna Dórea Gonzaga de Menezes ${ }^{[\mathrm{c}]}$, Bruno Oliveira Gonçalves ${ }^{[\mathrm{d}]}$, Robson da Silva Almeida ${ }^{[a]}$, \\ Anderson Reis Santos ${ }^{[\mathrm{d}]^{*}}$
}

[a] Universidade Estadual de Santa Cruz (UESC), Ilhéus, Bahia, Brazil

[b] Universidade Federal de São Paulo (Unifesp), São Paulo, Brazil

[c] União Metropolitana de Educação e Cultura (UNIME), Itabuna, Bahia, Brazil

[d] Hospital Calixto Midlej, Itabuna, Bahia, Brasil

\section{Abstract}

Introduction: Although manual hyperinflation (MHI) is a physical therapy technique commonly used in intensive care and emergency units, there is little consensus about its use. Objective: To investigate the knowledge of physical therapists working in intensive care and emergency units about manual hyperinflation. Methods: Data were collected through self-administered questionnaires on manual hyperinflation. Data collection took place between September 2014 and January 2015, in Itabuna and Ilhéus, Bahia, Brazil. Results: The study sample was composed of 32 physical therapists who had between 4 months and 10 years working experience. All respondents affirmed that they used the technique in their professional practice. However, only $34.4 \%$ reported it to be a routine practice. $90.6 \%$ stated that the most common patient position during manual hyperinflation is "supine". Participants were almost unanimous (93.8\%) in

RVSC: MS, e-mail: rafaviny@gmail.com FSSDA: PhD, e-mail: fabi4000@gmail.com PDGM: PhD, e-mail: polly_dorea@yahoo.com.br BOG: BS, e-mail: brunoliveira7@hotmail.com RSA: MS, e-mail: robsonfisio1@hotmail.com 
citing secretion removal and cough stimulation as perceived benefits of MHI. High peak airway pressure was identified as being a precaution to treatment with MHI by $84.4 \%$ of participants, whilst $100 \%$ of the sample agreed that an undrained pneumothorax was a contraindication to MHI. Conclusion: The most common answers to the questionnaire were: supine position during MHI; secretion removal and cough stimulation as perceived benefits; high peak airway pressure as a precaution; and an undrained pneumothorax as a contraindication.

Keywords: Intensive Care Unit. Emergency. Physical Therapists. Respiratory Therapy. Inflation.

\title{
Resumo
}

\begin{abstract}
Introdução: a hiperinsuflação manual é uma técnica fisioterapêutica comumente empregada no ambiente de terapia intensiva e emergência, no entanto há pouco consenso sobre sua utilização. Objetivo: investigar o nível de conhecimento dos fisioterapeutas atuantes em unidades de terapia intensiva e setores emergências acerca da manobra de hiperinsuflação manual. Métodos: Foram entregues questionários acerca do conhecimento sobre hiperinsuflação manual para os fisioterapeutas atuantes em terapia intensiva e/ ou setor de emergência em hospitais nos municípios de Itabuna e Ilhéus - Bahia. A coleta ocorreu entre setembro de 2014 e janeiro de 2015. Resultados: participaram 32 fisioterapeutas, cujo tempo de atuação profissional variaram entre 4 meses e 10 anos. Todos os entrevistados afirmaram que técnica é utilizada em sua prática profissional, no entanto, apenas $34,4 \%$ afirmaram que seu emprego é uma atividade de rotina no seu cotidiano laboral, 90,6\% afirmaram que a posição mais comum dos pacientes durante a realização da técnica é a posição supina. Quantos aos benefícios percebidos, a remoção de secreção e o estímulo à tosse foram quase unânimes (93,8\%), a precaução mais frequente foi o alto pico de pressão inspiratória (84,4\%) e a contra-indicação relatada por 100\% da amostra foi o pneumotórax não drenado. Conclusão: posição supina durante a técnica, percepção do estímulo de tosse e remoção de secreção, o entendimento do alto pico de pressão inspiratória como precaução e pneumotórax não drenado como contra-indicação foram as respostas mais uniformes dentre os entrevistados.
\end{abstract}

Palavras-chave: Unidade de Terapia Intensiva. Emergência. Fisioterapeutas. Terapia Respiratória. Insuflação.

\section{Introduction}

Historically, the work of physical therapists in Intensive Care Units (ICUs) has been associated with the improvement of respiratory function in critically ill patients; for different reasons, they may have an impaired mechanism of mucociliary clearance (MC). Structural airway defects, altered mucus composition and mucociliary clearance, lifestyle habits such as smoking or abnormal cough mechanics all contribute to reducing MC activity $[1,2]$. The accumulation of secretion in the lower respiratory tract, which is associated with an ineffective cough, may lead to the proliferation of microorganisms and to an increased predisposition for pulmonary infections [3].

According to the II Diretrizes brasileiras no manejo da tosse $\left(2^{\text {nd }}\right.$ Brazilian Guideline for cough management) [4], cough control may be voluntary or involuntary, and involve the following phases: inspiratory, compressive, expiratory and relaxatory. The greater the inspiratory phase, the greater the effectiveness of the cough. Mucus clearance is directly related to air speed in the airways, which may reach approximately $2500 \mathrm{~cm} / \mathrm{s}$. Changes in flow rate or the pressure required for it facilitate a defense mechanism of the airways, which may lead to deterioration of lung function. Inefficient $\mathrm{MC}$ and the volume of inspired air, combined with alterations in the cough reflex arc and/or sedatives and narcotics commonly used in ICUs, may diminish or even suppress coughing. Thus, the appropriate means to induce coughing and promote turbulent flow with the goal of clearing the airways will be impaired [5].

Neurodegenerative surgeries decrease conditions and upper cough effectiveness, abdominal or thoracic leading to retention of 
secretions in the airways, thus predisposing to areas of hypoventilation and pulmonary collapse. At the same time, mechanical ventilation, also used in intensive care settings, contributes to decreased mucociliary clearance and increased mucus production, in turn leading to the emergence of respiratory infections, which includes ventilator-associated pneumonia $[2,4,6]$. Pulmonary complications might also contribute to the reduction of lung function and an increase of ventilator dependence and oxygen supplementation. This corroborates the need to implement respiratory physical therapy to promote changes in pulmonary mechanics: The ventilatory alterations achieved will probably last for at least one hour [7].

Collateral ventilation, formed by interalveolar communications (pores of Kohn), channels of Lambert (bronchoalveolar channels) and Martin (interbronchiolar communication) start to function at 6-years-old, and assist secretion removal and redistribution of air from the 16th bronchial generation; this is considered to be the gas diffusion area, but in the absence of air flow, it can easily experience alveolar collapse [8].

One of the techniques used to optimize MC is manual hyperinflation (MHI), often called bag squeezing, which was developed in 1968 to improve oxygenation, clear bronchial secretions, and achieve alveolar re-expansion. MHI increases transpulmonary pressure and enhance collateral ventilation of obstructed alveoli, moving secretions fom peripheral to central airways and improving lung compliance [4, 9 - 12].

Despite certain divergences in its definition, MHI is widely recognized as a technique that mimics the physiological mechanism of a cough, by using a manual resuscitation bag to deliver tidal volumes (Vt) $100-150 \%$ larger than baseline Vt and a peak airway pressure of no more than $40 \mathrm{cmH}_{2} \mathrm{O}$, delivering a slow inspiratory flow, followed by a inspiratory hold and a fast expiratory flow that generates a whirlwind peak expiratory flow $[13,14]$. In the turbulent flow that is generated, the fluid spins erratically through different paths, increasing interactions with the tube wall and contributing to the removal of fluids and secretions $[15,16]$.

The number of sets of breath varies from 3 to 12 sets per minute. The inspiratory hold time varied from 2 to 5 seconds, with 2-3 seconds being the most frequently reported time interval. As explained in the original version of the technique, MHI can be used alone or in combination with expiratory chest compression.

The patient is positioned supine or the side, with the affected lung uppermost. The application time varies from 5 to 30 minutes $[6,12,14]$. The combined use of physical therapy techniques, such as postural drainage and MHI may potentiate their benefits and contribute to a more lasting effect on patients' clinical stability and hemodynamics [17].

This study aimed to investigate the knowledge of physical therapists working in intensive care and emergency units in Itabuna and Ilhéus about manual hyperinflation, its indications, contraindications, application techniques and physiological effects.

\section{Methods}

This observational, cross-sectional study used intentional, non-probability sample designs. It included two hospitals located in Itabuna and Ilhéus, in the south of Bahia, Brazil. Both hospitals had emergency and intensive care units and had physical therapists as members of the health care team.

The main researcher contacted the management of each of the potential physical therapy units and hospitals to explain the research objectives and request authorization to conduct data collection. Inclusion criteria were being a professional physical therapist (of both sexes, regardless of age), working at an emergency or intensive care unit for at least three months and signing the informed consent form.

Exclusion criteria were not being permanent members of the unit, being temporarily absent (due vacation, sick leave, personal leave, etc.) or not fully completing the questionnaire.

The data were collected through self-administered questionnaires, between September 2014 and January 2015. Questions on social and working conditions were based on the study by Junior, Gonçalves and Barbosa (18), whilst knowledge of manual hyperinflation was assessed through a closed questionnaire based on the study by Hogdson et al. [19]. The data were stored in a SPSS (version 19) database from which all the statistical analyses were performed.

This study was approved by the Research Ethics Committee of the Faculdade Adventista de Fisioterapia (FAFIS), opinion number 792.309. 


\section{Results}

The study included three Intensive Care Units (ICU) located in Itabuna, and three ICUS and one emergency unit located in the city of Ilhéus. Professionals who worked in more than one of the sites studied here were requested to complete the questionnaire only once.

The sample was composed of 32 physical therapists. $59.4 \%$ were male, $56.3 \%$ were married and the majority (21.9\% and $15.6 \%$ ) had been born in Itabuna and Ilhéus, respectively. Mean age was $31.93 \pm 3.27$ years and the mean length of time since completion of undergraduate degree was $7.78 \pm 3.80$ years. The mean length of time working at ICU was $4.16 \pm 2.61$ years and the amount of experience working at the job ranged from 4 months to 10 years.

Seventy-one point nine percent (71.9\%) completed undergraduate degree at a private university, 96.9\% reported having postgraduate certificates (in different specialties, not only hospital/intensive care), 3.1\% had master's degrees and $3.1 \%$ were $\mathrm{PhD}$ students.

Fifty-nine point four percent $(59.4 \%)$ of participants worked exclusively in Itabuna; $21.9 \%$ worked only in Ilhéus; $12.5 \%$ worked in both cities; $3.1 \%$ worked both in Itabuna and Salvador; and 3.1\% worked in Itabuna and Jequié. Only $12.5 \%$ worked as physical therapists at the emergency unit. This is due to the fact that only one of the two hospitals studied had physical therapists as members of the emergency unit: the one located in Ilhéus.

All respondents stated that they used MHI as a physical therapy treatment technique, but only $34.4 \%$ responded that $\mathrm{MHI}$ was a routine treatment at their work units $46.6 \%$ of respondents stated that, if available, they would include a PEEP valve in the bagging circuit.

Forty point six percent $(40.6 \%)$ of physical therapists did not know the highest peak airway pressure accepted in their work units with MHI and $37.5 \%$ used $30 \mathrm{cmH}_{2} \mathrm{O}$. Only $12.5 \%$ of respondents used a pressure manometer in the MHI circuit to assess the pressure given. The average application time of MHI was less than 5 minutes $(87.5 \%)$ and 10 minutes $(12.5 \%)$. Five breaths per set was the most common answer given by participants (62.5\%).

$90.6 \%$ of respondents stated that "supine" was the most common patient position for the use of MHI while $9.4 \%$ of respondents chose "side-lying with the affected lung uppermost" as their most common patient position.

As shown in Table 1, when asked about the most common components of a MI treatment, $59.4 \%$ of respondents chose "quick release of resuscitation bag" while $31.7 \%$ chose "vibrations".

Table 1 - Components used during manual hyperinflation

\begin{tabular}{lc}
\hline Manual hyperinflation components & (\%) \\
\hline PEEP valve in circuit & 0 \\
Vibrations & 31.7 \\
Quick release of resuscitation bag & 59.4 \\
Inspiratory hold & 78.1 \\
Slow deep inspiration & 31.3 \\
TOTAL & $\mathbf{1 0 0}$ \\
\hline
\end{tabular}

Table 2 shows that there was good agreement amongst respondents as to the perceived benefits of MHI. 93.8\% perceived that removal of secretions and cough stimulation were important benefits of MHI.

Table 2 - Perceived benefits of manual hyperinflation

\begin{tabular}{ll}
\hline Benefits of manual hyperinflation & (\%) \\
\hline Reinflation of atelectasis & 34.4 \\
Removal of secretions & 93.8 \\
Stimulate a cough & 93.8 \\
Improve lung volumes & 68.8 \\
Improve oxygen saturation & 78.1 \\
Improve lung compliance & 34.4 \\
TOTAL & 100 \\
\hline
\end{tabular}

When asked about the precautions and contraindications to $\mathrm{MHI}, 84.4 \%$ of respondents identified high peak inspiratory pressure as being a precaution to treatment with MHI while all participants stated that an undrained pneumothorax was a contraindication to $\mathrm{MHI}$ (Table 3). 
Table 3 - Precautions and contraindications to treatment with manual hyperinflation

\begin{tabular}{lcccc}
\hline & Precaution & Contraindication & Neither of the two & No response \\
\hline High peak inspiratory pressure & $84.4 \%$ & $12.5 \%$ & $0.0 \%$ & $3.1 \%$ \\
Undrained pneumothorax & & $100 \%$ & & \\
Unstable cardiovascular system & $31.3 \%$ & 68.8 & & $3.1 \%$ \\
Raised intracranial pressure or $\mathrm{TBI}^{1}$ & $25 \%$ & $71.9 \%$ & $6.3 \%$ & $0.0 \%$ \\
Bronchospasm & $62.5 \%$ & $31.3 \%$ & $3.1 \%$ & $6.3 \%$ \\
PEEP > 10 $\mathrm{cmH}_{2} \mathrm{O}^{2}$ & $62.5 \%$ & $28.1 \%$ & 17 & $0.0 \%$ \\
Acute pulmonary edema & $37.5 \%$ & $43.8 \%$ & $8 \%$ & $6.3 \%$ \\
ARDS & & & $3.1 \%$ & $3.1 \%$ \\
\hline Hemoptysis & $62.5 \%$ & $28.1 \%$ & $0.0 \%$ & \\
\hline
\end{tabular}

Note: ${ }^{1} \mathrm{TBI}$ - Traumatic Brain Injury, PEEP2 - positive expiratory pressure, ARDS ${ }^{3}$ - Acute Respiratory Distress Syndrome.

\section{Discussion}

MHI is a treatment technique commonly used by physical therapists in intensive care units for passive lung inflation, intensification of elastic recoil forces, enhancement of the peak expiratory flow, and consequent clearance of secretions accumulated in the airways [20]. According to Ambrozin et al. [21], MHI consists of slow deep inspirations, followed by an inspiratory hold and a quick pressure release using a manual resuscitation bag. This promotes increased expiratory flow rate, moving secretions trapped in the lungs and reopening collapsed lung areas. For Ortiz et al. [22], the technique is intended to promote removal of bronchial secretions and re-inflation of atelectasis, improving lung compliance and oxygenation of patients receiving mechanical ventilation.

Hogdson et al. [19] conducted a survey to examine the use of MHI by physical therapists in Australian hospitals. Seventy-six per cent of respondents stated that MHI was a routine treatment on ventilated patients and the most common treatment time was 10 minutes. In this study, only $34.4 \%$ of physical therapists responded that MHI was a routine treatment technique. The most common treatment time was 5 minutes, and the second most common treatment time was 10 minutes. Thus, knowledge of the technique and its clinical indications are essential to guide professionals in its application; and it may or may not be associated with other techniques of respiratory physical therapy.
A study with mechanically ventilated patients conducted by Berney, Denehy [23] showed that the use of both manual and ventilator hyperinflation improve static pulmonary compliance and clear similar volumes of pulmonary secretions.

A systematic review conducted by Reid et al. [24] to address whether secretion removal techniques increase airway clearance in patients with chronic spinal cord injury found that manual hyperinflation combined with assisted cough improved cough efficacy by increasing peak expiratory flow, and provided the most consistent, high-level evidence. Improved cough and clearance of pulmonary secretions were the benefits most commonly reported by participants.

It is important to stress that disconnecting a patient from mechanical ventilation to apply MHI presents some risks, such as an abrupt decrease in pulmonary pressure and loss of alveolar recruitment. Ventilator hyperinflation is a safer, more effective alternative and, when used in combination with (previous) PEEP, gives better clinical and hemodynamic results [25, 26]. Nevertheless, Chaves [27] states that a lower variability in pulse oxygen saturation (SaO2) levels can be achieved through the inclusion of a positive expiratory pressure (PEEP) valve in the bagging circuit used for MHI, since it improves ribcage stability.

There was good agreement on the most common patient position for the use of MHI: $90.6 \%$ of respondents chose "supine" as the most common patient position. This is in accordance with the study conducted by Berti et al. [12]. Gravity plays a 
significant role in the displacement of secretions. The positioning of the most affected lung in the gravityindependent side for the use of MHI, combined or not with other secretion clearance techniques, improves the efficacy of bronchial hygiene therapy $[4,19]$. Postural drainage follows the structure of the airways with regard to dependent and non-dependent ventilation, favoring the action of gravity over the diameter of the alveolus, and thus facilitating drainage [28].

The use of MHI in pediatric patients seems to be useful to clear the airways of children with acute respiratory failure or in recovery following heart congenital disease and upper abdominal surgery, bone marrow transplantation, asthma, tracheal reconstruction, brain injury, airway injury, and heterogeneous lung diseases. This technique increases spontaneous tidal volume and improves chest $\mathrm{x}$-ray appearance and the oxygenation index $\left(\mathrm{PaO}_{2} / \mathrm{FiO}_{2}\right)[20]$. As regards the monitoring of passive pulmonary mechanics in infants, obtained by complete relaxation of the respiratory muscles after the use of respiratory techniques such as HMI, it is necessary to induce the Hering-Breuer reflex, triggered by the rapid obstruction of the airway (for 1 second) at the end of normal inspiration to compare the improvement achieved with the technique [29].

Pattanshetty \& Gaude [6], on their turn, investigated if the use of techniques of respiratory physical therapy combined with MHI and vibrocompression would reduce the incidence of pneumonia in mechanically ventilated patients. There was a significant reduction in respiratory infection in patients in the intervention group, when compared to the control group, which received only MHI combined with tracheal aspiration. In this study, only $31.7 \%$ of respondents reported using vibration in combination with MHI.

An undrained pneumothorax or hemothorax was considered to be an absolute contraindication to MHI, because it increases the volume of air in the pleural space (in case of unidirectional fistulas), and consequently increases lung collapse and hemodynamic instability. In case of trauma when less than $20 \%$ of the lung is affected, physical therapists usually choose an expectant conduct, paying attention to a possible deterioration of the respiratory condition before, during and after the intervention. Nevertheless, when more than $20 \%$ of the lung is affected, thoracic drainage is recommended, as well as physical therapy intervention after drainage [30 - 32].
While in this study $21.8 \%$ of physical therapists identified hemoptysis as a precaution to $\mathrm{MHI}$, in another study it was identified as so by $83 \%$ of participants [19]. In addition to the risk of barotrauma, HMI may also be associated with other risks, such as changes in mean arterial pressure, and should therefore be employed with caution in hemodynamically unstable patients [25].

Although $84.4 \%$ of physical therapists identified high peak inspiratory pressure as being a contraindication to $\mathrm{MHI}$, only $12.5 \%$ used a pressure manometer in the bagging circuit. This result is corroborated by the findings by King and Morrell apud Hodgson et al. [19], who investigated the use of MHI in public hospitals in the United Kingdom. They found that $98 \%$ of physical therapists considered high peak inspiratory pressure to be a contraindication or a precaution to $\mathrm{MHI}$, but only $31 \%$ used a pressure manometer.

Despite its benefits for the removal of secretions and opening of the airways, MHI may cause barotrauma (in the case of high peak pressure), volutrauma and hemodynamic instability [23]. MHI efficacy may be influenced by professionals' lack of experience and/ or the brand of the manual resuscitation circuit used, as well as by the resistance and compliance of the respiratory system [25]. In neurological patients, MHI combined with aspiration may temporarily increase intracranial pressure and reduce mean arterial pressure and venous return, but has no noxious effects on cerebral perfusion [24]. A study conducted by Ferreira [32] showed that airway clearance techniques or intratracheal aspiration using MHI, manual vibration and postural drainage, for instance, improve intracranial pressure without clinical repercussions or without changing cerebral perfusion.

A study conducted with eight physical therapists in São Paulo, Brazil, found a great variability in the way in which MHI was employed. This suggests a worrying ventilatory pattern in terms of secretion removal, because the use of MHI caused low peak expiratory flow and tidal volume, despite high proximal pressures and peak inspiratory pressure [25].

Thus, although many studies confirm the benefits of MHI, broad opinions exist as to the perceived benefits and the way in which MHI is employed. Future studies needed to investigate how the technique is used and perceived by physical therapists working in intensive and emergency care. 
The authors of this study believe that the lack of standardized guidelines and scientific consensus, as well as the lack of collaboration of some physical therapists (when completing the questionnaire) might have compromised the sample size and the collection and dissemination of information on the resources available for physical therapy in emergency and intensive care settings. The non-existence of ethics committees in the hospitals studies is another factor that hinders the motivation to participate in or conduct studies that are important not only to improve everyday practice but also patient care as a whole.

\section{Conclusion}

There is considerable variation in technical knowledge and use of manual hyperinflation in inhospital physical therapy, but strong agreement on preferred treatment position (supine), precaution (high peak airway pressure), contraindication (undrained pneumothorax) and perceived benefits (secretion removal and cough stimulation).

Further studies are needed to investigate the understanding and usage of MHI by physical therapists who treat patients with artificial airways requiring bronchial hygiene therapy, and to examine the benefits and intrinsic risks of MHI. Moreover, further studies should be conducted to compare the existing literature and determine if the use of different application times, number of breaths per set, and components affects the outcomes of MHI.

\section{References}

1. McCool FD, Rosen MJ. Nonpharmacologic airway clearance therapies: ACCP evidence-based clinical practice guidelines. Chest. 2006;129(1 Suppl):250S-9S.

2. Strickland SL, Rubin BK, Drescher GS, Haas CF, O'Malley CA, Volsko TA, et al. AARC clinical practice guideline: effectiveness of nonpharmacologic airway clearance therapies in hospitalized patients. Respir Care. 2013;58(12):2187-93.

3. Lopes AJ, Noronha AJ, Mafort TT. Mecanismos de defesa do aparelho respiratório. Rev Hosp Univ Pedro Ernesto. 2010;9(2):11-6.
4. II Diretrizes brasileiras de manejo da tosse crônica. J Bras Pneumol. 2006;32(Suppl 6):S403-46.

5. Munkholm M, Mortensen J. Mucociliary clearance: pathophysiological aspects. Clin Physiol Funct Imaging. 2014;34(3):171-7.

6. Lemes DA, Zin WA, Guimaraes FS. Hyperinflation using pressure support ventilation improves secretion clearance and respiratory mechanics in ventilated patients with pulmonary infection: a randomised crossover trial. Aust J Physiother. 2009;55(4):249-54.

7. Moreira FC, Teixeira C, Savi A, Xavier Rogério. Alterações da mecânica ventilatória durante a fisioterapia respiratória em pacientes ventilados mecanicamente. Rev Bras Ter Intensiva. 2015;27(2):155-60.

8. Alvares BR, Pereira IMR, Mezzacappa MA, Stopiglia MS, Pires CS. Atelectasia pulmonar em recémnascidos: etiologia e aspectos radiológicos. Sci Med. 2012;22(1):43-52.

9. Pattanshetty RB, Gaude GS. Effect of multimodality chest physiotherapy in prevention of ventilatorassociated pneumonia: A randomized clinical trial. Indian J Crit Care Med. 2010;14(2):70-6.

10. Maxwell LJ, Ellis ER. Pattern of ventilation during manual hyperinflation performed by physiotherapists. Anaesthesia. 2007;62(1):27-33.

11. Lemes DA, Guimarães FS. 0 uso da hiperinsuflação como recurso fisioterapêutico em unidade de terapia intensiva. Rev Bras Ter Intensiva. 2007;19(2):221-5.

12. Berti JSW, Tonon E, Ronchi CF, Berti HW, Stefano LM, Gut AL, et al. Hiperinsuflação manual combinada com compressão torácica expiratória para redução do período de internação em UTI em pacientes críticos sob ventilação mecânica. J Bras Pneumol. 2012;38(4):477-86.

13. Paulus F, Veelo DP, de Nijs SB, Beenen LFM, Bresser P, de Mol BA, et al. Manual hyperinflation partly prevents reductions of functional residual capacity in cardiac surgical patients - a randomized controlled trial. Crit Care. 2011;15(4):R187.

14. Berney S, Haines K, Denehy L. Physiotherapy in Critical Care in Australia.Cardiopulmonary. Cardiopulm Phys Ther J. 2012;23(1):19-25. 
15. Rodrigues MVH. Estudo do comportamento hemodinâmico, da troca gasosa, da mecânica respiratória e da análise do muco brônquico na aplicação de técnicas de remoção de secreção brônquica em pacientes sob ventilação mecânica [dissertation]. São Paulo: Universidade de São Paulo; 2007.

16. Godoy ACF. Física básica aplicada à fisioterapia respiratória. Arq Ciênc Saúde. 2006;13(2):103-7.

17. Nunes GS, Botelho GV, Schivinski CIS. Hiperinsuflação manual: revisão de evidências técnicas e clínicas. Fisioter Mov.2013;26(2):423-35.

18. Souza Jr ED, Gonçalves LR, Barbosa MMC. Estudo do perfil profissional dos fisioterapeutas na cidade de Belém [undergraduate thesis]. Belém: Universidade da Amazônia; 2008.

19. Hodgson C, Carroll S, Denehy L. A survey of manual hyperinflation in Australian hospitals. Aust J Physiother. 1999;45(3):185-93.

20. Godoy VCWP, Zanetti NM, Jonhston C. Manual hyperinflation in airway clearance in pediatric patients: a systematic review. Rev Bras Ter Intensiva. 2013;25(3): 258-62.

21. Ambrozin ARP, Gonçalves ACC, Rosa CM, Navega MT. Efeitos da higienização brônquica nas variáveis cardiorrespiratórias de pacientes em ventilação mecânica. Fisioter Mov. 2013;26(2):251-8.

22. Ortiz TA, Forti G, Volpe MS, Carvalho CRR, Amato MBP, Tucci MR. Experimental study on the efficiency and safety of the manual hyperinflation maneuver a secretion as a secretion clearance technique. J Bras Pneumol. 2013;39(2):205-13.

23. Berney S, Denehy L. A comparison of the effects of manual and ventilator hyperinflation on static lung compliance and sputum production in intubated and ventilated intensive care patients. Physiother Res Int. 2002;7(2):100-8.

24. Reid WD, Brown JA, Konnyu KJ, Rurak JM, Sakakibara BM. Physiotherapy secretion removal techniques in people with spinal cord injury: a systematic review. J Spinal Cord Med. 2010;33(4):353-70.
25. Brooks D, Anderson CM, Carter MA, Downes LA, Keenan SP, Kelsey CJ, et al. Clinical practice guidelines for suctioning the airway of the intubated and nonintubated patient. Can Respir J. 2001;8(3):163-81.

26. Dornelas BR. PEEP versus Aspiração Convencional na Remoção de Secreções em Pacientes Sob Ventilação Mecânica Invasiva. Rev Bras Cien Med Saúde. 2015;3(3):1-8.

27. Chaves CP. Repercussões da manobra de bagsqueezing com e sem válvula reguladora de pressão positiva expiratória final em recém-nascidos prétermos sob ventilação mecânica prolongada [master's disseratation]. São Paulo: Universidade de São Paulo; 2013.

28. Silva KM, Bromerschenckel AIM. Fisioterapia respiratória nas doenças pulmonares obstrutivas crônicas. Rev Hosp Univ Pedro Ernesto. 2013;12(2):94-100.

29. Lanza FC, Wandalsen GF, Cruz CL, Solé D. Impacto da técnica de expiração lenta e prolongada na mecânica respiratória de lactantes sibilantes. J Bras Pneumol. 2013;39(1):69-75.

30. Nóbrega KCC, Pereira JVM, Costa DS. Intervenção fisioterapêutica em casos de pacientes admitidos por trauma torácico: um estudo retrospectivo. Rev Estação Cientifica. 2012;2(1):43-54.

31. Abreu EMS, Machado CJ, Pastore Neto M, Rezende Neto JB, Sanches MD. Impacto de um protocolo de cuidados a pacientes com trauma torácico drenado. Rev Col Bras Cir. 2015;42(4):231-7.

32. Ferreira LL, Valenti VE, Vanderlei LCM. Fisioterapia respiratória na pressão intracraniana de pacientes graves internados em unidade de terapia intensiva: revisão sistemática. Rev Bras Ter Intensiva. 2013;25(4):327-33.

Received on $06 / 19 / 2016$ Recebido em 19/06/2016

Approved on 09/18/2017 Aprovado em 18/09/2017 